\title{
Accelerating Internationalization of Financial Management to Boost Implementation of "the Belt and Road" Initiative
}

\author{
Shaohua Wang ${ }^{1}$, Huafeng Zhang ${ }^{2}$ \\ ${ }^{1}$ Xijing University, Xi'an Shaanxi, 710123, China \\ ${ }^{2}$ Qinnong Bank, Xi'an Shaanxi, 710000, China
}

Key words: Financial management, Internationalization, "The Belt and Road" Initiative.

\begin{abstract}
The implementation of "the Belt and Road" Initiative creates good conditions and god-given historic opportunity for Chinese enterprises to go global. In the face of brand-new development form, large and medium enterprises in China should become the backbone force to promote the development of this initiative. The implementation of "the Belt and Road" Initiative proposes new requirements for business management. In order to better avoid financial risks in foreign operation and competition process, enterprises need to keep enhancing financial management and really connect with the world. Enterprises face huge difficulties in the process of going global. Internationalization of financial management can better cope with the risks from foreign market and finally facilitate enterprises to better gain a firm foothold in international market. In combination of actual conditions, this paper firstly analyzes the challenges to financial management of enterprises in the process of implementing "the Belt and Road" Initiative and then proposes the countermeasures to accelerate internationalization of financial management, in the hope of offering certain help for the peers.
\end{abstract}

\section{Introduction}

Complex and profound changes are happening to the current world. The deep-level influence of international financial crisis continues to intensify. The world economy recovers slowly, and serious differentiation problem occurs in the development process. Investment pattern in the international trade and investment rules of multilateral trade are being adjusted profoundly. All countries are faced with very severe problems. As the largest developing country, China generates profound influence on the pattern of world economy. Under such era background, the state president Xi Jinping put forward the proposal of Silk Road Economic Belt and Maritime Silk Road in the new century during visiting East Asian countries and received the attention of many countries. The proposal and implementation of "the Belt and Road" Initiative accord with era development course and the development trend of economic integration, and trigger a tide of going global in China. How should large and medium enterprises in China better carry out transnational operation in the process of going global? Every enterprise needs to consider this problem in the process of implementing "going global" strategy. International production and operation among multiple countries and enterprises need to confront politics, economy and culture of different countries and enterprises. Thus, enterprises should really achieve internationalization of financial management and avoid various risks of international operation. In combination of actual conditions, this paper mainly analyzes the measures to accelerate internationalization of financial management so as to better boost the implementation of "the Belt and Road" Initiative.

\section{Deep meaning of the proposal of "the Belt and Road" Initiative}

On September 8, 2013 and October 3, 2013, Xi Jinping put forward the idea of Silk Road Economic Belt and Maritime Silk Road in the new century during delivering a speech at Nazarbayev University in Kazakhstan and Indonesian parliament, respectively. The core idea is to make sure economic cooperation of various countries becomes closer, mutual cooperation among countries becomes 
deeper and development space becomes wider. Besides, it is required to innovate the cooperation mode and gradually form regional cooperation. Xi jinping stressed that various countries should achieve mutual benefit and win-win result and proposed the concept of benefit community and development community. The proposal and implementation of "the Belt and Road" Initiative is an important strategic decision made by the highest decision-making level in China in order to actively cope with the profound development changes of global economy and plan domestic and internal economic situations as a whole. It is a great decision for China's future economic development, reform, stability, prosperity and even great rejuvenation of Chinese nation.

At present, China's economy steps in normalization and deep water district. Economic growth slows down. Structural adjustment is faced with a huge problem. The stimulus policy in the early stage gradually enters the digestion period. Under such background, the 18th National Congress of the Communist Party of China pays high attention to reform, proposes the strategy of continuing to deepen reform and expand opening, repositioned the new normalcy of national economic development and maintains sustainable growth and moderate growth of national economy. In addition, new changes happen to the structure of world economy under the conflict of international financial crisis, and the growth pattern of world economy changes. Developed economic entities suffer such impacts as debts and the lack of investment opportunities. Industrial production capacity drops, and unemployment rate increases. The leading role of developed economic entities in global economic growth has fluctuated. In 2016, China's contribution to world economy exceeds 10\%, while economic contribution rate of US and Europe gradually declined. Emerging and developing economic entities kept a high growth rate and gradually became the main driving force to stabilize national economic growth. As global economic integration advances, regional economic integration course speeds up. Developing countries around China including ASEAN, Central Asia and South Asia own rich regional resources and broad development potential. They urgently need to increase development vigor through cooperation. "The Belt and Road" Initiative was proposed under such background. The proposal of "the Belt and Road" Initiative constructs more open new economic system for China, and enterprises have more opportunities to participate in international market competitions. Apart from the development opportunity, the implementation of "the Belt and Road" Initiative also brings about large challenges to enterprises. In the complex and varied international market, enterprises need to strengthen management and especially do financial management well so as to evade international market operation risks and really achieve the internationalization of financial management.

\section{The implementation of "the Belt and Road" Initiative brings about challenges to financial management of enterprises}

The implementation of "the Belt and Road" Initiative accelerates the process of global economic integration so that enterprises face complex international trade environment in international market competitions. Meanwhile, fierce competitions among enterprises are also intensified. To survive and develop in such a complex environment, enterprises must adopt modern business management means to enhance their competitive capacity. An enterprise with competitive edge not just depends on the operation scale and production capacity. Financial management is a very important job. But in current stage, the researches on internationalization of financial management are not deep, and relevant theories are immature. Enterprises are confronted with many problems in the implementation process, mainly including the following aspects:

\section{Strategic management awareness of enterprises is weak}

In financial management of enterprises, strategic management is a very important component. It is an operation and management mode which aims to achieve long-term development of enterprises by analyzing international and domestic market factors and helping enterprises formulate operation strategies beneficial to their development. Currently, many export enterprises in China have weak strategic consciousness, blindly pursue economic benefit in the process of going global and fail to 
clearly confirm the overall development planning and development strategy. Especially in the process of foreign investment and project construction, enterprises cannot combine development trend and demand of local market for analysis, and financial analysis is only based on the macroscopic level of international market. Besides, enterprises invest blindly.

\section{There is lack of international financial management personnel}

At present, many enterprises own numerous financial management employees and accounting employees, but there is lack of high-quality financial management employees who master international financial management rules and management knowledge. Under international production and operation environment based on the implementation of "the Belt and Road" Initiative, financial management employees of enterprises require the ability to comprehensively analyze the factors influencing enterprises, foreign and national markets so as to help enterprises formulate operation and management strategies from strategic level, except financial management knowledge. At present, many enterprises in China pay insufficient attention to internationalization of financial management. Thus, relevant theoretical and practical researches are very few, and a complete theoretical system fails to form. Moreover, professional training idea of financial management personnel falls behind. Existing financial management personnel cannot be qualified for the requirements in the process of implementing "the Belt and Road" Initiative.

\section{Financial management of enterprises is faced with external environment challenge}

The implementation of "the Belt and Road" Initiative has been the focus of the central government in recent years. Its implementation makes China more open and form the new pattern of opening to the outside world. The external problem that Chinese enterprises face in the process of foreign trade, investment and project construction changes to complex international operation problem from previous simple domestic operation problem. On the one hand, the state becomes more open, and enterprises have to confront the influence of multiple aspects such as politics, economy, culture and society of capital export countries. In particular, different countries have different business rules, legal systems and industrial standards. Thus, financial management personnel of enterprises need to do researches well on politics, economy, culture and society of capital export countries so as to make sure enterprises own good coping capacity, except routine financial management work. On the other hand, most countries along the line of "the Belt and Road" are emerging economic entities and developing countries, so their demand for products is not very large. Besides, economic environment and financial environment in some regions are not sound. If enterprises fail to do overall survey and analysis in advance and invest blindly, huge operation and production risks may occur to the enterprises.

\section{Countermeasures to accelerate internationalization of financial management}

\section{To enhance political risk prevention}

Political risk is the largest risk that enterprises face in foreign operation process. Before the investment, financial management department of an enterprise should overall analyze investment climate of capital export country, do risk evaluation work well and help the enterprise make a correct investment decision. Financial management department of an enterprise should actively engage in investment climate evaluation process and actively take actions after finding uncertain factors influencing investment security and income. Moreover, it is necessary to disperse investment subjects to ensure investment and financing diversification and localization. Meanwhile, it is necessary to set up joint venture enterprises locally to disperse enterprise operation risk. In the process of financial decision-making, financial management department of an enterprise should take into account of local political factor, always keep strong vigilance for political factor of capital export countries, and formulate proper prevention measures in advance for potential political risks to minimize enterprise risks. 


\section{To strengthen management of foreign exchange risk}

Foreign exchange risk is an inevitable financial risk in financial management process of export enterprises. Thus, enterprises are required to continuously improve management level for foreign exchange risk and review foreign exchange risk from the perspective of beforehand prevention. Firstly, export enterprises should pay attention to the selection of currency in the operation process and strive to collect the currency with stable market value and pay the currency with depreciation trend. In the practical operation process, currency collection, transaction, borrowing and repayment should be consistent as far as possible so as to minimize exchange rate risk. If currency options are few in foreign operation process, enterprises need to scientifically evaluate the risk of exchange rate fluctuation in the negotiation process, consider the price difference caused by exchange rate fluctuation and specify in the contract that customers need to compensate certain exchange loss after the currency exchange rate fluctuation exceeds certain range. Furthermore, Chinese enterprises should actively recommend native currency in the foreign operation process, and try to regard RMB as the currency of price or currency of settlement in project negotiation process. Secondly, in the implementation of the Belt and Road" Initiative, enterprises should be good at utilizing multiple trading instruments provided by financial market to avoid the risk of exchange rate fluctuation.

\section{To enhance management of offshore funds}

Centralized management of funds is to centralize idle funds of each department in an enterprise, uniformly deploy and balance funds to achieve mutual complementation of internal funds, reduce external financing, the amount of loans and scale and decrease financial cost. During centralized management of domestic funds, enterprises achieve centralized management of funds in the form of financial settlement center or finance corporation. Centralized management of offshore funds in foreign operation process will involve many countries and regions, and the environment is complex and varied. Thus, the risks are very high. Fund business and international financial environment have a close tie. Meanwhile, many currencies of other countries will enter the capital flow in international business. In this way, enterprises will face huge foreign exchange risks. For some countries with very strict foreign exchange management, it is very hard for the idle funds to return to China in time. So, centralized management of offshore funds differs a lot from centralized management of domestic funds. Thus, export enterprises must overall cognize and grasp the process, law and risk involved in centralized management of offshore funds, have foresight for the possible risks and improve active prevention awareness. Enterprises should closely grasp the change trend of international financial market and currency exchange rate, grasp economic development trend, political situation, development degree of financial industry, tax policy and fund management policy of capital export countries, study offshore fund settlement and fund flow rule and enhance the foresight and initiative in centralized management of offshore funds so as to effectively prevent offshore fund management risk.

\section{To do training well for financial management risk}

Financial management personnel of enterprises play a very important role in implementing foreign operation and "going global" strategy, and concern enterprise survival and development. Therefore, enterprises should focus on training and education of financial management personnel, cultivate financial talents, and make sure financial management personnel own professional knowledge and ability as well as the ability to predict financial management development trend. Besides, enterprises need to expand diversified financial management training, improve risk management, prevention and control ability of financial management team, establish an international financial management team and finally facilitate sustainable development of enterprises. 


\section{References}

[1] Gan Junxian, The Belt and Road Initiative for India: Walking Alone or Dancing with China? , International Studies. 2015(04).

[2] Liu Yang, Risk Research on Important Natural Resources in the Period of "the 13th Five-year Plan", Macroeconomic Management. 2015(06).

[3] Pan Zhiping, The Unforeseeable Future of the 2015 Central Asian Situation, China Investment. 2015(03).

[4] Guo Chunmei, Reasons for Obstruction of Chinese Investment in Macao and the Enlightenment, Contemporary International Relations. 2014(10).

[5] Dong Manyuan, Influence and Prospect of the Rise of "Islamic State", International Studies. 2014(05).

[6] Sun Degang, On China's Soft Military Presence in the Middle East in the New Era, World Economics and Politics. 2014(08).

[7] Yang Chenxi, Great Power Factor in "the Belt and Road" Regional Energy Cooperation and Coping Strategy, Expanding Horizons. 2014(04).

[8] Qian Xuming, The Base of "the Silk Road Economic Belt and the Marine Silk Road" Strategy: China and the Middle East Energy Cooperation, Arab World Studies. 2014(03). 